\title{
Assessing the potential for pocket agriculture in mountainous regions: A case study in West Kootenay, British Columbia, Canada
}

\author{
Rachael Roussin ${ }^{a}$ and Julie E. Wilson ${ }^{b}$ \\ University of British Columbia \\ Gregory Utzig $^{c}$ \\ Kutenai Nature Investigations Ltd. \\ Les M. Lavkulich $\mathrm{d} *$ \\ University of British Columbia
}

\begin{abstract}
Submitted March 6, 2015 / Revised May 8, July 24, and October 13, 2015 / Accepted October 14, 2015 /
Published online December 21, 2015

Citation: Roussin, R., Wilson, J. E., Utzig, G. \& Lavkulich, L. M. (2015). Assessing the potential for pocket agriculture in mountainous regions: A case study in West Kootenay, British Columbia, Canada. Journal of Agriculture, Food Systems, and Community Development, 6(1), 175-188. http://dx.doi.org/10.5304/jafscd.2015.061.016
\end{abstract}

Copyright (C) 2015 by New Leaf Associates, Inc.

\author{
Abstract \\ Food security is a growing concern for rural \\ communities that rely on imported food. \\ a Rachael Roussin, Graduate Associate, Master of Land \\ and Water Systems (MLWS), University of British \\ Columbia; Rossland, British Columbia V0G $1 Y 0$ \\ Canada; rachael.roussin@gmail.com \\ b Julie E. Wilson, Academic Coordinator, MLWS, \\ University of British Columbia; Vancouver, B.C. V6T \\ 1Z4 Canada; mlws.program@ubc.ca \\ c Gregory Utzig, P.Ag., Principal, Kutenai Nature \\ Investigations Ltd.; Nelson, B.C. V1L 5K5 Canada; \\ g13utzig@telus.net \\ $\mathrm{d} *$ Corresponding author: Dr. Les Lavkulich, Professor \\ Emeritus, University of British Columbia; Vancouver, \\ B.C. V6T 1Z4 Canada; +1-604-822-6360; \\ $\underline{\operatorname{lml} @ \text { mail.ubc.ca }}$
}

Increasing a region's food self-reliance is a strategy to address this concern, but is a challenge in regions with limited arable lands as a result of topographically diverse, mountain-dominated landscapes. Mechanized, large-scale agriculture relies on contiguous areas of arable land, rather than small parcels of dispersed arable soils and suitable climates. The Kootenay region of British Columbia, Canada, serves as an example of the opportunities for mountainous, rural communities to increase their food self-sufficiency by considering the potential for agriculture on small parcels of land. Soil capability survey maps that provide a biophysical assessment of arable lands were used as a basis for determining (a) the potential land base available for small-scale agriculture, and (b) the potential for niche crops that may be grown on poorer capability lands in 
the Kootenay region. The soil capability criteria, coupled with farm survey data, were used to measure and quantify the distribution of underutilized farmland in the region. Results indicate that up to 90 percent of land capable of agriculture and 69 percent of high quality farm land protected under the Agricultural Land Reserve is not under production for crops or pasture. Global Climate Model scenarios for 2050 indicate that the region will have a longer growing season, hotter summers, and more frost-free days, which could increase the region's capacity to grow food but might require additional water for irrigation. The assessment suggests that soil surveys based on biophysical attributes can assist mountainous regions in assessing their potential for agriculture.

\section{Keywords}

small-scale agriculture, climate change, local food production, pocket agriculture, soil surveys, agricultural capability, food security

\section{Introduction}

As recently as the 1950s, much of the food consumed in the West Kootenay region of British Columbia (B.C.) was grown or raised locally, whereas now about 95 percent of food consumed is imported from outside the region (Brynne Consulting, 2011). B.C. currently imports about CA $\$ 2$ billion worth of food each year, including most of its fruit and vegetables, and is highly dependent on the state of California (U.S.) for most of this produce (Ostry, 2010; Ostry, Miewald, $\&$ Beveridge, 2011). The reliance on food that is sourced from far away has exposed the vulnerability of many communities' food systems to climatic events such as the recent droughts in California (Crawford \& Beveridge, 2013; Dai, 2013). The uncertainties that climate change places on reliable food imports have led to the promotion of local agriculture as a suggested policy strategy for B.C. (Ostry et al., 2011).

There are regions of many countries, including Canada, that have not developed intensive agricultural enterprises, in part due of the lack of large contiguous landscapes with arable soils to facilitate today's technically sophisticated agriculture. The West Kootenay region of southeastern B.C. is an example of one of these regions. In this region, settlement and industrial development was initiated by resource-extractive industries dominated by forestry and mining (Turnbull, 1988). Although there was limited agriculture to meet the needs of the local citizenry, there was also little incentive or opportunity to develop a viable and sustainable basis for commercial agriculture. The rugged landscapes, the relatively few contiguous areas of productive soils, the large diversity of microclimatic conditions expressed over short distances, and the relative mobility of the work force were factors that negated the establishment of a commercial mechanized agricultural industry. Settlers within the region did establish small parcels of crop production to meet within-season food requirements, and agriculture was established in some larger river valleys.

Local governments and organizations in the West Kootenay recently have identified the reliance on food imports as a vulnerability to adapting to the impacts of climate change (Columbia Basin Trust, n.d.-a). Producing more food locally has been identified as a resilience strategy and also an economic opportunity, and this has spurred interest and research on local agricultural development in the region (Brynne Consulting, 2011; Columbia Basin Trust, n.d.-a; Steinman, 2011). Climate change may actually have the potential to create agricultural opportunities in the West Kootenay by extending the growing season and expanding the varieties of fruits and vegetables that might be grown.

Food self-sufficiency can be defined as being able to meet a region's consumption needs (particularly for staple food crops) from its own production rather than by buying or importing (Minot \& Pelijor, 2010). The B.C. Ministry of Agriculture and Lands (2006) suggests that to achieve food selfsufficiency from a land-based perspective, about one-half a hectare ( 0.5 hectare) of farmland is needed to produce the food for one person for one year, given the production technologies available today. Although this is an oversimplified way to evaluate food self-sufficiency, it does provide a land-based measure and could include small parcels, or pockets, of arable land that provide opportunities to increase local food production. 
It is from a land-based perspective that we have chosen to investigate the agricultural potential of the West Kootenay and its relevance to food self-reliance in the region.

\section{Farmland in the West Kootenay Region}

As a result of British Columbia's mountainous terrain, less than 5 percent of the total provincial land base is considered arable or potentially arable (Green, 2006). Of this, about 600,000 hectares (ha) (1.5 million acres) are in crops and 1.61 million hectares (3.98 million acres) are used for pasture or grazing (B.C. Ministry of Agriculture, 2011). Farms on lot sizes less than 4 hectares or 10 acres are defined as "Small Parcel Agriculture" and make up 29 percent of all B.C. farms (B.C. Ministry of Agriculture, 2011; Statistics Canada, 2011).

Arable soils in B.C. have been classified on the basis of their capability to support crops, in terms of Soil Capability for Agriculture (Runka, 1973). This classification system categorizes soil landscapes into a series of classes from Class 1 to Class 7 (best to least suited for soil-based, mechanized commercial agriculture). Most of the soil landscapes in the best classes (1-4) have been placed within the province's Agricultural Land Reserve (ALR), which was established in 1973 by the government of B.C. to permanently protect valuable agricultural land from being lost (Agricultural Land Commission, 2013; Green, 2006). Certain conditions that limit mechanized agriculture, such as excessive stoniness, topography, or soils with limited waterholding capacity, may result in a Class 5 rating, but may not be significant limitations for particular niche crops, such as tree fruits or grapes in areas which are climatically suitable (B.C. Ministry of Agriculture and Foods, 1983).

The Soil Capability for Agriculture classification does not consider several factors, including the productivity of any specific crop, the distance to market, available transportation, hazards of crop damage due to storms, nor economic viability. The soil capability classification system as developed in B.C. differs from other systems that rate the "suitability" of soil landscapes for agriculture, which are based on crop productivity (Green, 2006). The capability classification system is not restricted to productivity of present crops common in the region; instead, it presents the potential of the range of crops that could be grown, thus serving a more proactive planning process (Green, 2006).

In the West Kootenay region, the total amount of farmland, including its primary limitations to crop production, are largely unknown. The ALR provides an estimate of the amount of land reserved for agricultural purposes for mechanized agriculture (Classes 1-4), but does not include land (e.g., Class 5 soils) that might be suitable for niche crops or tree fruit production.

Agriculture in North America, including British Columbia, is dominated by large-scale, highly mechanized management on relatively large and contiguous land holdings. In mountainous regions, large contiguous land areas are usually not available, restricting agricultural activities to small localized areas. This is the situation in the Kootenay region. We introduce the concept of 'pocket agriculture' to identify small parcels of land that can be used for agricultural uses that do not require large holdings or climate regimes that are conducive to a range of crops, but have potential to serve local food needs. As Miller et al. (2013) posit, society should optimize resilience by developing food chains that incorporate risk and complexity, which entails creating local, national, and global systems that better capture change and learning. These scenarios embrace adaptation and opportunities for multiple types of food production, integrating traditional and novel approaches to attain food security.

Thus, although the West Kootenay region does not contain large tracts of contiguous land for today's mechanized agriculture, the question becomes, if there is a need and interest in local food production, is there an opportunity to develop pocket agriculture in the region?

As such this study's three objectives are to:

1. Assess the area of arable lands within the West Kootenay region;

2. Identify the soil and climate challenges and potential for small-parcel agriculture; and

3. Make a preliminary assessment of the effects of climate change on this potential for small-parcel agriculture. 


\section{Methods}

Study Area

\section{West Kootenay agricultural land}

The Kootenay region comprises the Kootenay Boundary, Central Kootenay, and East Kootenay districts in the Southern Interior of British Columbia. The West Kootenay study area comprises all areas within the Regional District of Central Kootenay and areas A, B, and C in the Regional District of Kootenay Boundary, for a total of $2,484,575$ ha or 6,139,519 acres (Figure 1). The study area includes several urban centers (Trail, Rossland, Nelson, Castlegar, Creston, Salmo, Nakusp, and Kaslo) and, combined with rural areas, is home to approximately 70,000 residents.

\section{Soil capability and climate}

The most suitable soils for agriculture (Class 1-4) in the study area are located on fluvial and lacustrine deposits (Jungen, 1980). Moderate

limitations of these soil for agriculture include poor soil drainage on the floodplains, poor soil structure in the lacustrine areas, and low moisture-holding capacity on the sandy terraces. Other areas suitable for arable agriculture include some glaciofluvial terraces, fluvial fans, and glacial till deposits. Limitations of these soils include adverse topography, low soil moisture-holding capacity, stoniness, and a short annual frost-free period. Class 5 soils have more severe limitations and are dispersed throughout the region on moderately sloping glacial till, coarse textured fans, stony glaciofluvial terraces, and some areas that are susceptible to flooding (Jungen, 1980). As mentioned earlier, although the definition of Soil Capability for Agriculture (Runka, 1973) includes only Classes 1-4, this study extended the definition of potentially arable soils to include Classes 5 and even 6 , in consideration of specialty or niche crops.

Climatic characteristics that affect crop

Figure 1. Map of the West Kootenay with Regional District Boundaries by Census Area
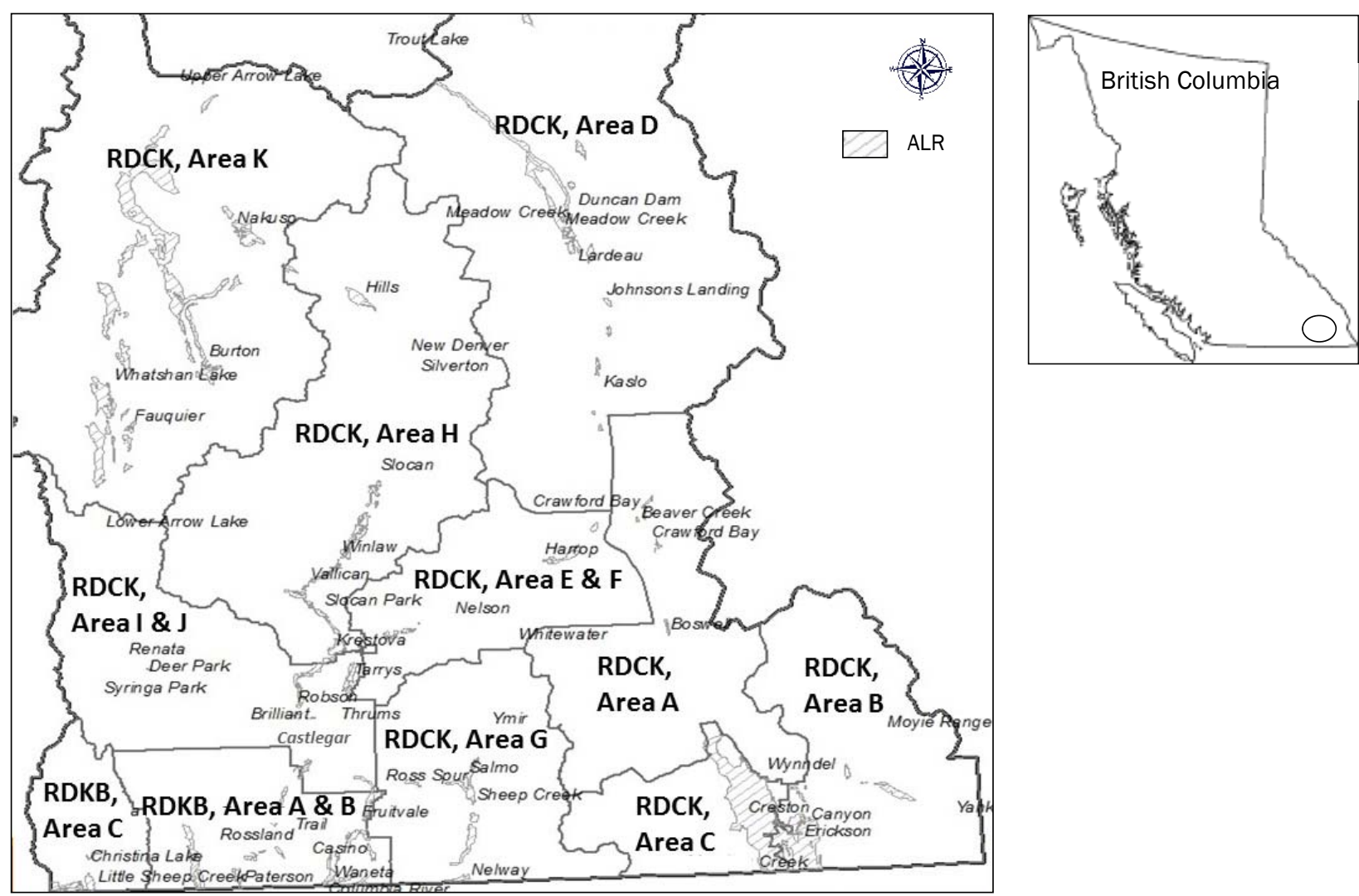

Note: Map generated in ArcGIS by the authors. 
production determine the potential agricultural capability of the land. Thus, Class 1 land must be located in an area which has at least a Class 1 climate capability for agriculture rating (Jungen, 1980). Precipitation and growing conditions are influenced by the mountainous topography and, as such, vary considerably throughout the region. Temperature is more consistent than precipitation; microclimates such as rain shadows and frost pockets exist in the region. Long-term records show a historic range of frost-free periods from 130 to 149 days, and greater variability in precipitation, with historic climate moisture deficits ranging from $-180 \mathrm{~mm}$ to almost $-400 \mathrm{~mm}(-7.09$ inches to almost -15.75 inches) (British Columbia Land Inventory, 1981).

\section{Analysis}

\section{Farmland data}

This study employed geographic information systems (GIS) to determine the amount of agricultural land in the West Kootenay region. Data sources included 1:125 000 maps of the Soil Capability for Agriculture classification (Canada Land Inventory, 1972) and the 1:50 000 agricultural capability GIS maps and data (B.C. Ministry of Environment, n.d.). The boundaries of the ALR were based on GIS files from B.C. Data Distribution Services (2014).

The study area included areas with digitized soil capability data for a total of 2,035,790 ha (5,030,547 acres), of which 65,750 ha or 162,472 acres (3.2 percent) are within the ALR.

Approximately 440,000 ha $(1,087,000$ acres $)$ were excluded from the analysis due to lack of data in a digitized format; however, these areas contained very little agricultural land.

This information was analyzed based on the unimproved Soil Capability Class ratings, which reflect the soil and climate conditions that existed at the time of the survey, without irrigation (Runka, 1973). Potential improvements that could result in an improved rating include drainage, irrigation, diking, stone removal, salinity alleviation, subsoiling, and the addition of fertilizer.

\section{Climate data}

Global Climate Models (GCM) from the Intergovernmental Panel on Climate Change's Fifth Assessment Report (2014) were downscaled (that is, localized) to the West Kootenay region using ClimateBC models for the Pacific Northwest and B.C. region (ClimateBC, desktop version) to project future climate scenarios to 2050. The models calculated seasonal and annual climate variables for specific locations based on latitude, longitude, and elevation. Three GCMs were chosen to represent the broad range of projected climate scenarios for 2050 with the RCP 8.5 scenario. The RCP 8.5 represents a "business-as-usual" scenario, meaning no measures would be taken to mitigate climate change or decrease in greenhouse gas emissions (Table 1).

Seven localities in the study area were chosen to downscale the climate scenarios. Multiple data points in GIS were taken in a one $\mathrm{km}$ (0.62 mile) grid for each location for all Class $1-5$ lands over 800 meters (2,625 feet) elevation and were averaged.

\section{Agricultural census data}

Data from the 2011 Canada Agricultural Census were used to estimate the land currently under crop production and in pasture in the West Kootenay region. The "Hectares in Crops" variable was used to quantify the amount of land currently under cultivation for field crops, tree fruits, vegetable, berry, and nut production. The "Farms Reporting" variable was used to show the number of farms growing different crops and the average area or size of farm. These variables do not include Christmas tree plantations, nurseries, sod and

\section{Table 1. Global Climate Models Used and Characteristics Analyzed for the West Kootenay Region, B.C.}

\begin{tabular}{ll}
\hline Global Climate Model & Characteristics \\
\hline HadGem & Hot/Dry \\
\hline GFDL & Very hot/Wet \\
\hline MRI & Warm/Moist \\
\hline
\end{tabular}

Models from Intergovernmental Panel on Climate Change, 2014 
mushrooms farms, summer fallow land, herbs, or garlic gardens. The census data only account for farms that report to Statistics Canada and therefore excludes backyard food production. As there is limited published information on suitable crops for the region, this information was augmented by guides and feasibility studies for crop production in other areas of Canada and the United States (Garland, 1990 Otto, 1993; University of WisconsinExtension \& University of Minnesota, 1992).

\section{Results}

The entire Kootenay region (East, Central and Boundary districts) has about 392,550 hectares (970,010 acres) in the ALR, which is approximately 8 percent of B.C.'s total agricultural land in the ALR. Of this total, 17.5 percent is in the West Kootenay region. The mountainous landscape of the West Kootenay limits agriculture, but pockets of arable land with a suitable climate permit the production of field crops, annual vegetables, tree fruits, berries, poultry, beef, and dairy. The area at Creston (Central Kootenay B and C) is the commercial agricultural center of the region, and its major crops are tree fruits, forage, and some grain. The Nakusp area (Central Kootenay Area K) has the most land in the ALR and produces the second highest amount of forage and alfalfa crops after Creston (Statistics Canada, 2011).

\section{West Kootenay Soil Capability and ALR Summary}

Class $1-4$ soils that can support a wide range of crops compose 5 percent of the total study area, while Class 5 soils that support forage, animal pasture, or specialty niche crops compose an additional 6 percent. Thus, about 11 percent of the total study area has some agricultural capability, for a total of 200,000 ha or 494,000 acres (Figure 2). Although agricultural land is limited in the region, in most areas it is underutilized and thus has potential for increased agricultural activity. Of the land classified as suitable for agriculture (Class 1-5), only 10 percent is under production for crops and pasture, or 31 percent of the ALR (Table 2).

The land zoned for agriculture (ALR) makes up 3.2 percent of the total study area. The majority of the land in the ALR is high quality, with 42 percent being prime agricultural land (Classes 1-3) and 40 percent being Class 4 . Lower capability classes compose very little of the ALR, with Class 5 making up 10 percent and Class 6 and 7 less than 8 percent (Table 3).

The majority of prime agricultural land in the region (Classes 1-3) is protected within the ALR. Only 6 percent of Class 5 land is protected in the ALR, and a negligible amount of Class 6 and 7 (Table 3).

Based on the B.C. Ministry of Agriculture's self-sufficiency estimate of approximately 0.5 hectare (1.24 acres) of land required to produce food for one person for one year (2006), 35,000 ha (86,500 acres) would be required for the West Kootenay's current population of 70,000 . There is insufficient Class 1-3 land to provide for 70,000 people (Figure 3); however, if Class 4 lands were included, it brings the total area of agricultural land (Class $1-4)$ to 86,000 ha $(212,500$ acres). The 66,000 hectares $(163,090$ acres $)$ in the ALR

\section{Figure 2. Percent of West Kootenay Study Area $(2,035,790$ ha or $5,030,550$ acres) in Soil Capability Classes 1-7}

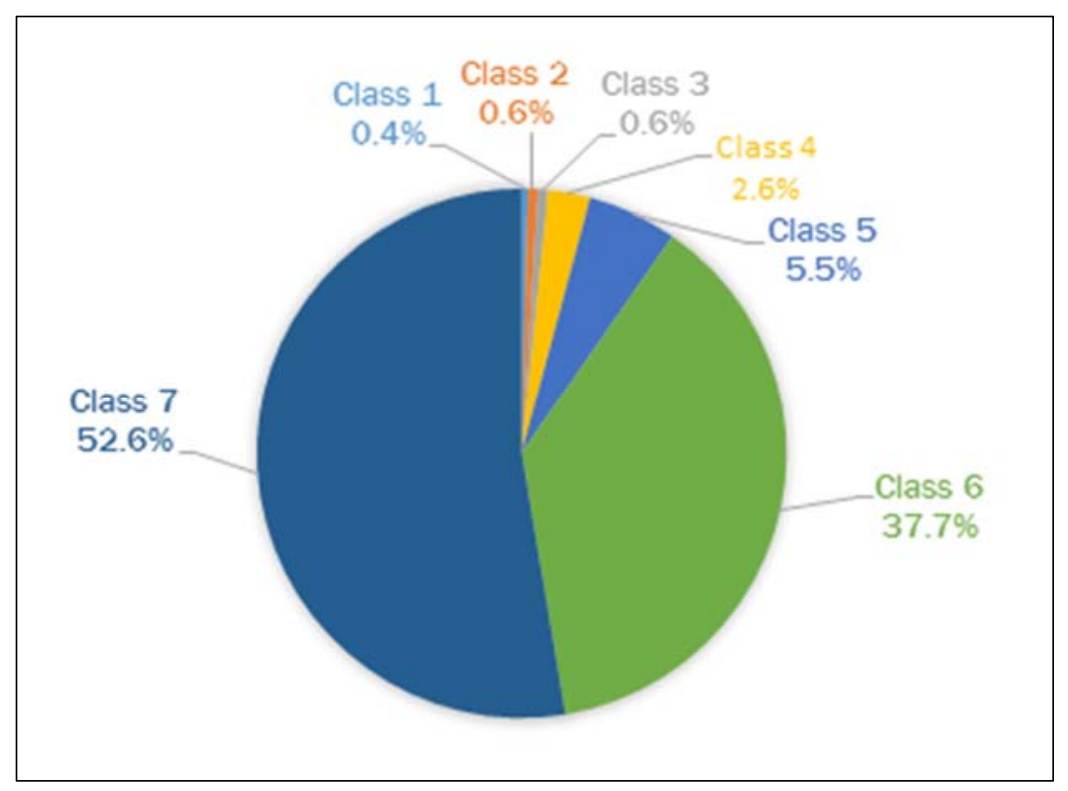


Table 2. Land Used for Agriculture as a Percent of the Agricultural Land Reserve by Regional District Electoral Area in West Kootenay, B.C.

\begin{tabular}{lcc}
\hline Regional District Electoral Area & $\begin{array}{c}\text { Land used for agriculture } \\
\text { (ha) (crops and pasture) }\end{array}$ & $\begin{array}{c}\text { Land used for agricul- } \\
\text { ture as \% of ALR (ha) }\end{array}$ \\
\hline Central Kootenay A & 218 | 539 & $44 \%$ \\
\hline Central Kootenay B & $5,118 \mid 12,647$ & $69 \%$ \\
\hline Central Kootenay C & $7,858 \mid 19,418$ & $65 \%$ \\
\hline Central Kootenay D & $259 \mid 640$ & $4 \%$ \\
\hline Central Kootenay E \& F & 377 | 932 & $34 \%$ \\
\hline Central Kootenay G & 882 | 2,179 & $36 \%$ \\
\hline Central Kootenay H & $1,257 \mid 3,106$ & $28 \%$ \\
\hline Central Kootenay J \& I & $576 \mid 1,423$ & $31 \%$ \\
\hline Central Kootenay K & 2,883 | 7,124 & $13 \%$ \\
\hline Kootenay Boundary B \& A & 1,002 | 2,476 & $21 \%$ \\
\hline Kootenay Boundary C & * & $31 \%$ \\
\hline Total & $\mathbf{2 0 , 4 3 0 ~ | ~ 5 0 , 4 8 4}$ & \\
\hline * Agricultural data amalgamated with Kootenay Boundary B & \\
\hline
\end{tabular}

Figure 3. Land Inventory and Land Use Comparison of the West Kootenay Region

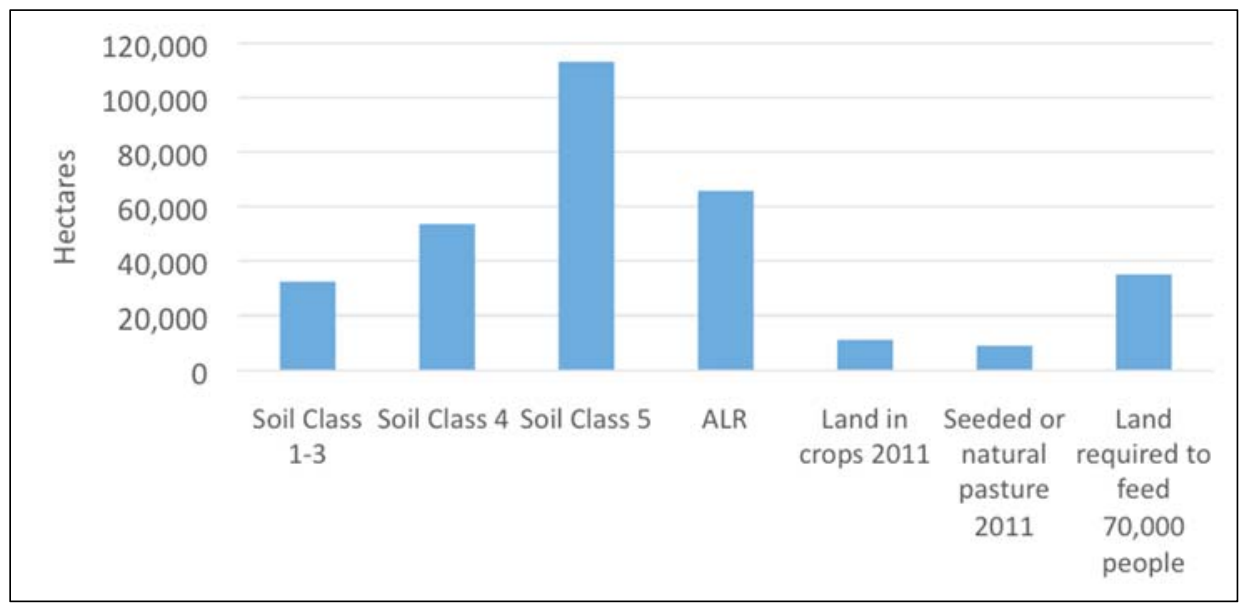

Note: 1 hectare $=2.47$ acres.

Table 3. Total ALR in the Study Area by Capability Class

\begin{tabular}{cccc}
\hline Capability Class ALR & Area (hectare | acre) & \% of total capability class & \% of ALR \\
\hline 1 & $7,000 \mid 18,000$ & $90.5 \%$ & $11 \%$ \\
\hline 2 & $10,994 \mid 27,167$ & $89.1 \%$ & $17 \%$ \\
\hline 3 & $9,551 \mid 23,601$ & $76.0 \%$ & $14 \%$ \\
\hline 4 & $26,279 \mid 64,937$ & $49.1 \%$ & $40 \%$ \\
\hline 5 & $6,724 \mid 16,615$ & $5.9 \%$ & $10 \%$ \\
\hline 6 & $3,699 \mid 9,140$ & $0.5 \%$ & $6 \%$ \\
\hline 7 & $1,488 \mid 3,677$ & $0.1 \%$ & $2 \%$ \\
\hline Total ALR study area & $65,737 \mid 162,440$ & $3.2 \%$ (of study area) & $100 \%$ \\
\hline
\end{tabular}


Regional Distribution of

Farmland

Regional District of Central

Kootenay (RDCK) Areas B, C and $\mathrm{K}$ have the highest amounts of prime agricultural land

(Figure 4) and the most hectares in the ALR. These areas also have the most hectares under agricultural production, demonstrating that farmland is currently being used in these areas (Table 2). Area D, in the northeastern portion of the study area, has the fourth largest area of high quality farmland and ALR but a minimal amount of land under agricultural production, with only 4 percent of land being used for crops or pasture compared to the ALR in this area (Table 2 and Figure 4). Many Regional District Areas have underutilized agricultural land, such as Central Kootenay Area G, which has 2,430 ha $(6,005$ acres $)$ in the ALR, of which only 36 percent is used for crops and pasture (Table 2).

\section{Agricultural Crops Grown}

The majority of crops cultivated in the West Kootenay region fall under the category of field crops, which include wheat, barley, sweet corn, corn for silage, potatoes, and forage such as alfalfa (Figure 5) (Statistics Canada, 2011). Of these, alfalfa hay and fodder are the most widely grown. The Creston area (Central Kootenay B and C) has the most hectares in field crops, with 7,190 ha (17,767 acres) and 215 farms reporting, while Central Kootenay Area K has 945 ha (2,335 acres) and 50 farms reporting. The remainder of the region combined has 1,000 ha $(2,471$ acres) with 128 farms reporting, indicating that the majority of larger scale commercial field crop production is in Creston (Figure 6).

Total gross farm receipts for 2010 support the crop data that suggest the scale of agricultural
Figure 4. Distribution of Farmland in the West Kootenay Region, B.C.

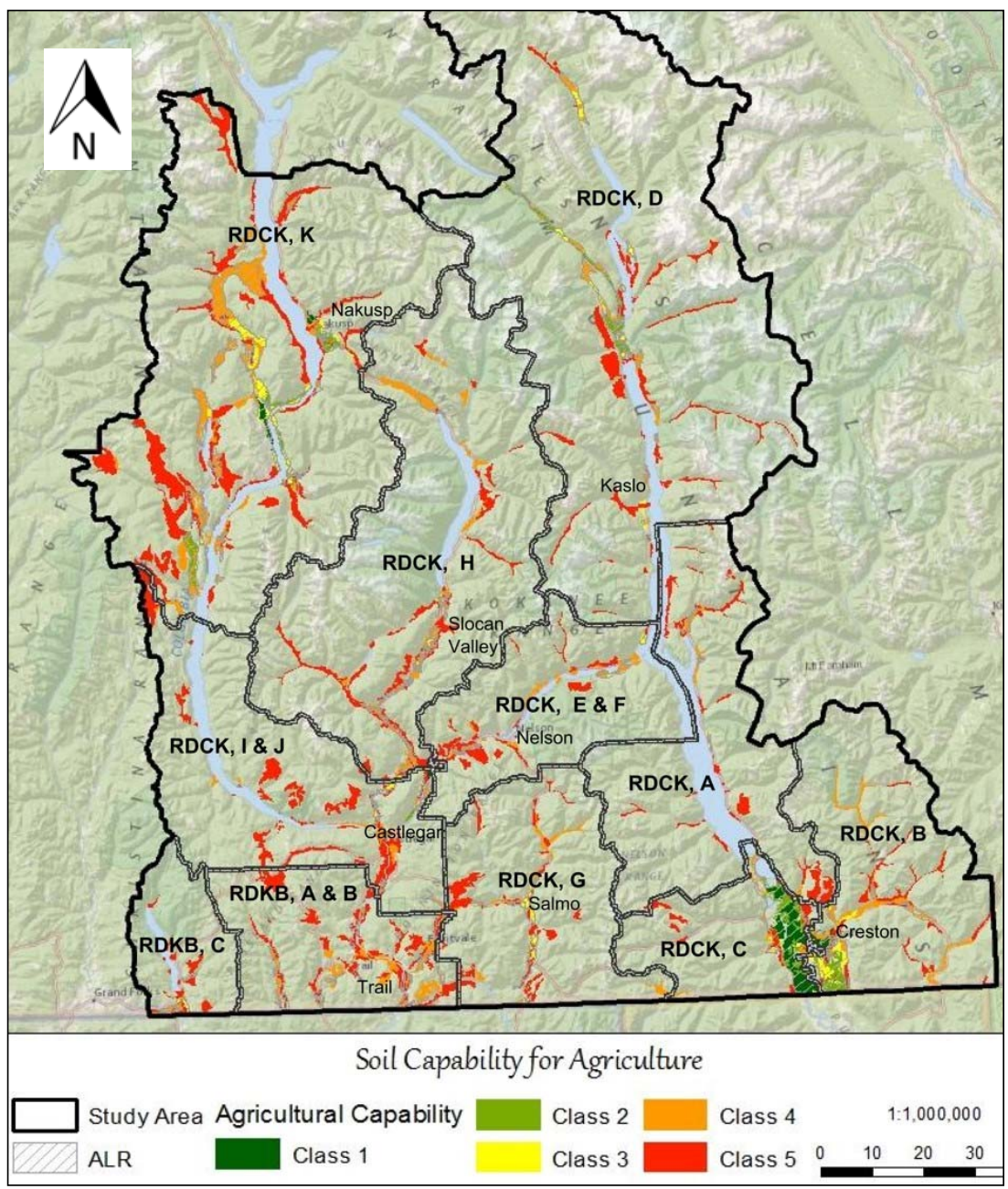

activity in the study area, outside of the Creston area, is dominated by small-scale enterprises with annual farm receipts mostly being less than $\mathrm{CA} \$ 50,000$.

The climate is favorable to a range of fruit and vegetable varieties, but it has historically limited the production of some perennial and annual crops that require mild winters, Growing Degree Days (GDD) greater than 2,000, and a Frost Free Period (FFP) greater than 160 days. A total of 262 hectares (647 acres) are in production for fruit, nut, and berry (Figure 5) with Creston reporting the most hectares of tree fruits, with the dominant crop being sweet cherry. Berry production is minimal in the region, with only 16 hectares (40 acres) under cultivation (in blueberry, strawberry and raspberry). Nut production is negligible. A diversity 
Figure 5. Land in Crops* (Hectares) and Number of Farms by Category (Excluding Pasture), 2011 Census Year. Note the break in the y axis indicating a rise in values.

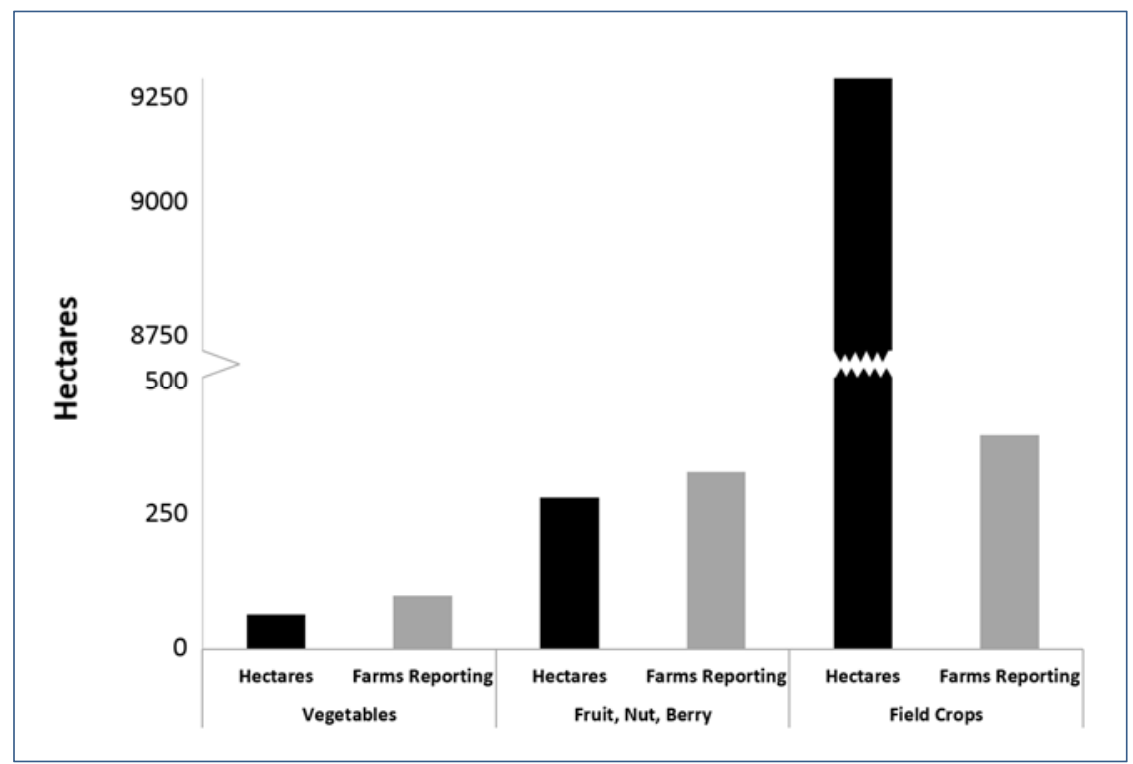

* Does not include greenhouse vegetables, seeded pasture, herbs (including garlic) or Christmas trees.

of annual vegetables are grown in the region on a total of 65 ha (161 acres) (Figure 5). The crop data do not represent the full amount of produce being grown in the region as the data is limited to farms that report to Statistics Canada and thus does not include production from backyard gardens.

\section{Figure 6. Total Land in Crops (Excluding Pasture) by Regional District} Area, 2011 Census Year

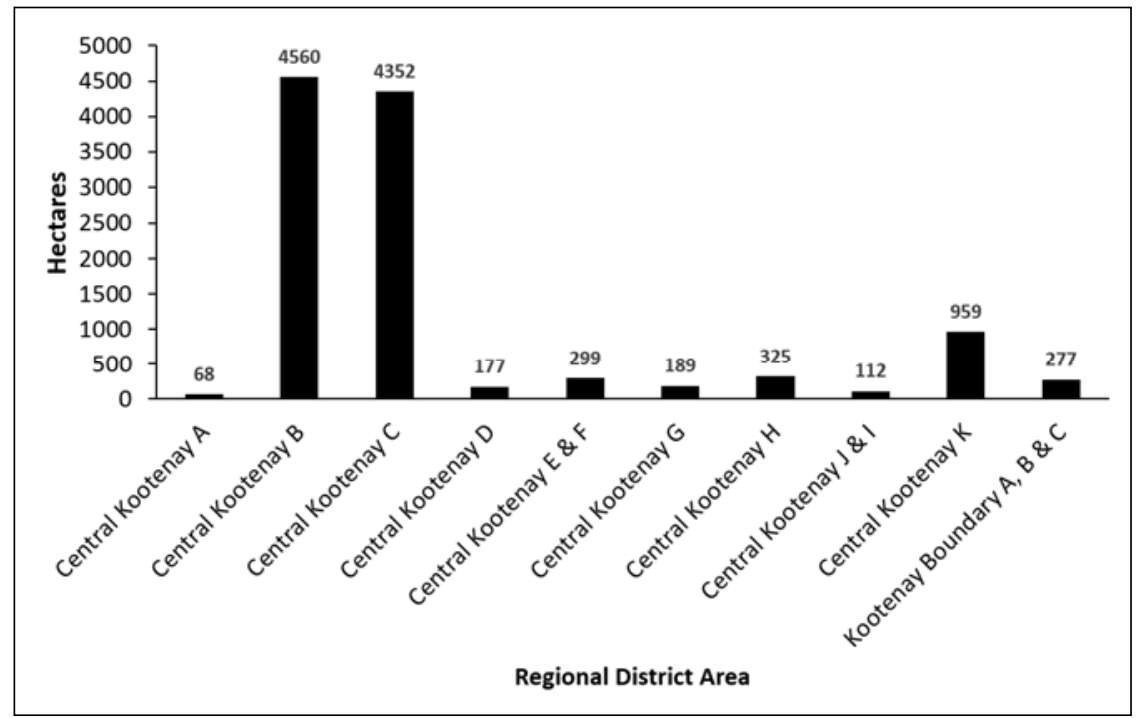

Global Climate Model

Projections

Climate change projections that simulate climatic scenarios to the year 2050 indicate a substantial increase in the FFP and GDD throughout the West Kootenay region. This could extend the growing season by approximately 30 to 90 days and increase the range of crops that can be grown.

Climate projections vary throughout the region, with cooler, moister climates projected in the North and some small microclimates in the South (Central Kootenay K, D and $\mathrm{G})$, while warmer and drier climates are projected in the South (Figure 1). All three GCMs suggest an increase in temperature-related variables by 2050 for the FFP (Figure 7), GDD (Figure 8), and Mean Warmest Month Temperature (MWMT).

The increase in the projected FFP illustrates the trend, with increases from 17 percent with the MRI GCM and up to 84 percent with the HadGem GCM (Figure 6). The MWMT is projected to increase by up to seven degrees in some areas and mean temperatures for each season show an increase including the winter.

Summer precipitation and Climate Moisture Deficit (CMD) show more variability among climate scenarios than the projections related to temperature. The MRI and GFDL scenarios suggest an increase in summer precipitation for most areas, and the HadGem model predicts a slight decrease. The CMD and warmer temperature projections suggest that all arable land will likely require 
Figure 7. Projected Frost-Free Period (Days/Year) for Two Localities in the West Kootenay Region for the Year 2050 (Compared to Historical Climate)

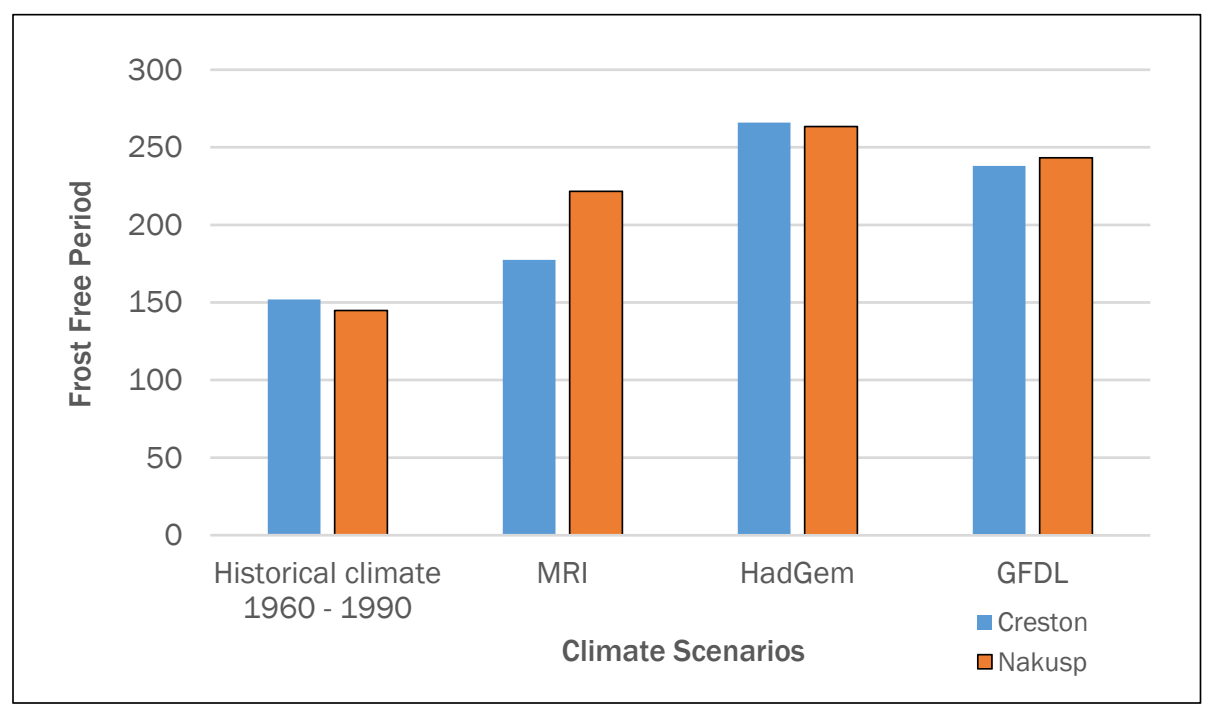

Figure 8. Projected Growing Degree Days above $5^{\circ} \mathrm{C}$ for Two Localities in the West Kootenay Region, for the Year 2050 (Compared to Historical Climate)

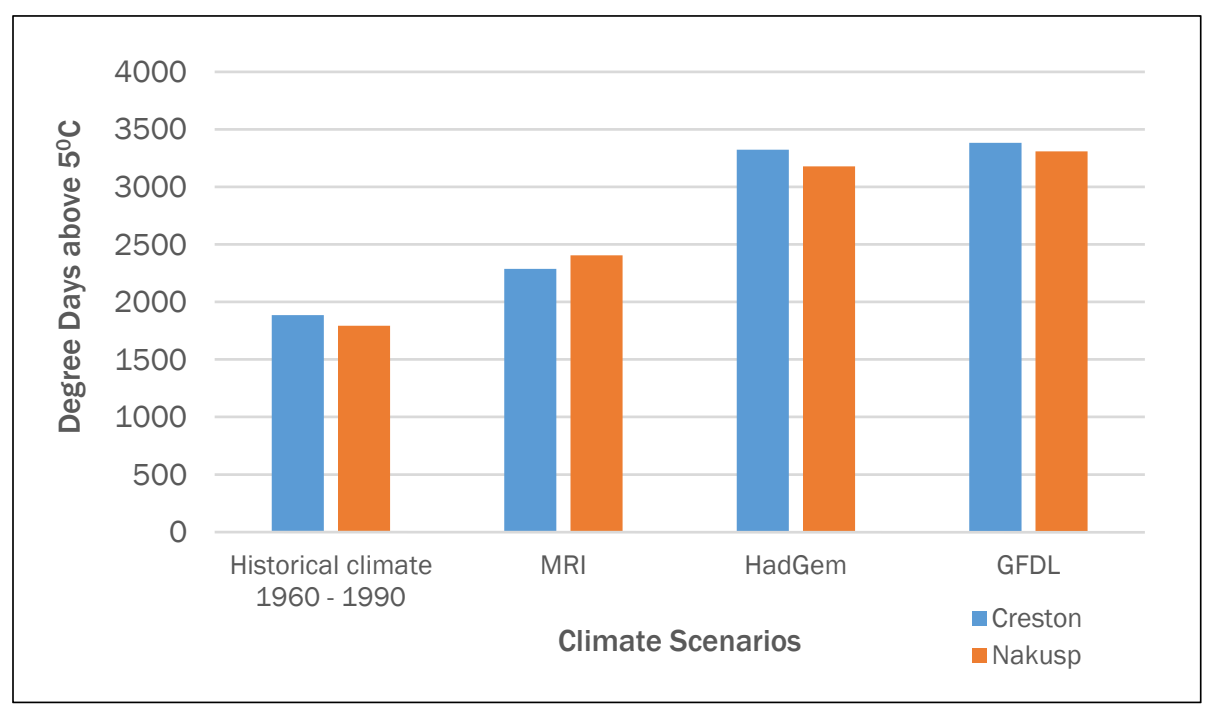

Classes 1-5 (or 31 percent of the ALR), is actually used for crops or pasture, meaning that there is high potential to increase agricultural production from a soil capability perspective. Underutilized farmland is distributed in pockets throughout the region, making small-scale agriculture the necessary production system (see Figure 9 for an example). With the concerns about the region's reliance on imported food and the introduction of mechanization for small-scale agriculture (Johansen, Haque, Bell, Thierfelder, \& Esdaile, 2012) there appear to be opportunities for local agriculture to satisfy some local consumption needs. For example, the Kootenay Co-op grocery store in the city of Nelson (population 10,000), which specializes in local products and sells over $\mathrm{CA} \$ 2$ million in produce annually, frequently experiences a supply gap. The store's produce manager stated that in increased irrigation with climate change, especially areas with the highest CMD.

\section{Discussion}

The Soil Capability for Agriculture classification scheme provides an initial tool to assess the agricultural potential for pocket agriculture in this mountainous region, and suggests that from a biophysical perspective there are opportunities to increase crop production in the West Kootenay. Only 10 percent of capable agricultural land,
2013 they could have purchased, each week, an additional 1,000-1,500 lb. of apples, 1,000 lb. of blueberries, 300-400 lb. of broccoli, and 400-600 lb. of melons (Kootenay Co-op produce manager, personal communication, May 2014).

Three GCM scenarios provide the most accurate climate projections while also demonstrating the range of uncertainty. A longer FFP could extend the season for annual vegetable crops, making it possible to produce more food through the year. Crops that may have historically been limited by 


\section{Figure 9. Earthy Organics Farm (Kootenay Boundary Area C), an Example of a Mixed Vegetable Farm on Class 4 and 5 Soils That Has Overcome the Limitations of Stoniness and Low Moisture-Holding Capacity}



Photo credit: Rachael Roussin, Earthy Organics Farm, Fruitvale, B.C., 2011.
Although there appears to be an abundance of fresh water in the region (both surface water and ground water), increasing human activities, population growth, and the projected impacts of climate change are placing pressure on water resources such that municipalities and organizations are collaborating to conserve water use (Columbia Basin Trust, n.d.c). Therefore, given the dependence on irrigation for crop productivity in the region, water requirements for increased agricultural development would need to be investigated further to fully understand the potential of the region.

A central limitation climate but that do well in marginal soils, such as tree fruits or grape, could be suitable for Class 5 soils, which are considered poor quality for mechanized agriculture.

Challenges exist to increasing food production. The total number of farms in the entire Kootenay region decreased by 9.4 percent between 2001 and 2011, and the area being farmed decreased by 18.6 percent. In addition, the average age of farm operators increased from about 54 to 57 years between 2006 and 2011, indicating that young people are either choosing not to farm or are having difficulty entering the agricultural sector (Columbia Basin Rural Development Institute, 2013). Land access for new entrants has been identified as a barrier to increased agricultural production in the region (North Kootenay Lake Community Services, 2013).

Climate change also presents potential challenges to local crop production, such as an increase in weeds and pests, drier soils, extreme climate events, and more water needed for irrigation (Columbia Basin Trust, n.d.-b). of this study is the assumption that an increase in local crop production will achieve greater food self-sufficiency for a region. There is a longstanding debate on whether food self-sufficiency is a useful strategy to achieve food security (Minot \& Pelijor, 2010). Increasing the food security level and developing a local food system involve a range of socio-economic and infrastructure considerations that are not addressed in this study.

\section{Conclusions}

Although the mountainous regions of British Columbia are not considered to be important agricultural areas due to the small extent of suitable soils for larger-scaled mechanized agriculture, in areas with underutilized farmland such as the West Kootenay, adaptations and adoptions of small-scale agriculture with a potentially more favorable future climate for crops could lead to an increased importance of pocket agriculture to meet local food security concerns and provide opportunities in the agricultural sector. 
The analysis using Soil Capability for Agriculture classifications revealed that there are substantial areas for expansion of agriculture in the West Kootenay region. The ALR protects 66,000 ha (163,090 acres) of the most valuable land for agriculture in the West Kootenay, with enough land to feed almost double the current population (based on the assumption that .5 ha or 1.24 acres is required per capita, per the usual British Columbian's diet). The region's capacity to feed itself is actually much greater, as there is a total of 86,000 ha (212,510 acres) of Class 1-4 lands that can support a wide range of crops, and 113,000 ha $(279,229$ acres) of Class 5 lands that are suitable for forage, animal pasture, and specialty niche crops. Only 10 percent of capable agricultural land (31 percent of the ALR) is actually used for crops or pastures; thus, using land quality as an indicator of agricultural potential, the West Kootenay is well situated to grow more food.

Climate change also presents potential opportunities to expand the range of crops that can be grown, extend the length of the growing season for annual vegetable crops, and make use of poorer quality lands for specialty niche crops, such as tree fruits and grapes whose cultivation has historically been limited by climate.

The results suggest that there is potential from a biophysical perspective to increase mixed smallscale agriculture in the West Kootenay region. The approach developed in this study could be adapted to many mountainous regions as a means to assess potential to increase local food production, especially for the more labor-intensive agricultural practices and the growing of fresh produce for local communities. We recognize that other issues, including socio-economic factors such as land access and the economic viability of small-scale farming, offer challenges to increasing the amount of land used for agricultural purposes, and that crop production does not necessarily equate to a regional food system nor confer food self-reliance or security. These issues are complex. The results of this study suggest that soil biophysical information, coupled with climate data and projections, can provide objective information on the agricultural potential of a region which then can be used by communities and governments as the initial step in understanding the crop production potential for increased regional food self-reliance.

\section{References}

Agricultural Land Commission. (2013). Agriculture capability \& the ALR fact sheet. Burnaby, British Columbia (B.C.), Canada: Provincial Agricultural Land Commission. Retrieved from http://www.alc. gov.bc.ca/assets/alc/assets/library/agriculturalcapability/agriculture capability the alr fact she et 2013.pdf

British Columbia [B.C.] Data Distribution Services. (2014). Agricultural Land Reserve boundaries [GIS data]. Victoria, B.C., Canada: DataBC. Retrieved from http://www.data.gov.bc.ca/dbc/geographic/

B.C. Land Inventory. (1981). Climatic capability classification for agriculture in British Columbia [APD Technical Paper 4]. Victoria, B.C., Canada: B.C. Ministry of Environment. Retrieved from http://www.alc.gov.bc.ca/assets/alc/assets/library Lagricultural-capability/climatic capability for agriculture_in_bc_1981.pdf

B.C. Ministry of Agriculture. (2011). 2011 Census of Agriculture: British Columbia highlights. Victoria, B.C., Canada: B.C. Ministry of Agriculture.

B.C. Ministry of Agriculture and Lands. (2006). B.C.'s food self reliance: Can B.C's. farmers feed our growing population? Victoria, B.C., Canada: B.C. Ministry of Agriculture. Retrieved from http://www2.gov. bc.ca/assets/gov/farming-natural-resources-andindustry/agriculture-and-seafood/agricultural-landand-environment/strengthening-farming/800series/820105-1 bcfoodselfreliance report.pdf

B.C. Ministry of Agriculture and Food. (1983). Land capability classification for agriculture in British Columbia. Kelowna, B.C., Canada: B.C. Ministry of Agriculture and Food. Retrieved from http://www.env.gov.bc.ca/wld/documents/ techpub/moe1/moem1.pdf

B.C. Ministry of Environment. (n.d.). Soil GIS Data, Agricultural Capability, 1:50,000. Retrieved December 2015 from http://www.env.gov.bc.ca/terrain/ terrain_files/standards.html

Brynne Consulting . (2011). Regional district of Central Kootenay agriculture plan. Nelson, B.C.: Regional District of Central Kootenay. Retrieved from http://www.rdck.ca/assets/Services/Land $\sim \mathrm{Use} \sim \mathrm{a}$ $\underline{\text { nd Planning/Documents/AG-Plan.pdf }}$ 
Canada Land Inventory. (1972). Soil capability classification for agriculture (Report No. 2). Ottawa, Ontario, Canada: Department of the Environment.

ClimateBC, desktop version [Computer software]. Vancouver, B.C., Canada: University of Columbia. Retrieved May 2014, from http://cfcg.forestry. ubc.ca/projects/climate-data/climatebcwna/

Columbia Basin Rural Development Institute. (2013). 2013 State of the Basin Long Report. Castlegar, B.C., Canada: Columbia Basin Rural Development Institute. Retrieved from http://www.cbrdi.ca/state-of-the-basin/

Columbia Basin Trust. (n.d.-a). Phase 1 and 2 community action plans. Retrieved July 2014 from http://adaptationresourcekit.squarespace.com/ community-action-plans/

Columbia Basin Trust. (n.d.-b). 5. Agriculture and food security. Retrieved June 2015 from http://adaptationresourcekit.squarespace.com/ food-security-and-agriculture/

Columbia Basin Trust. (n.d.-c). Water in the Columbia Basin [Brochure]. Castlegar, B.C., Canada: Columbia Basin Trust. Retrieved July 2014, from http://cbt.org/uploads/pdf/CBT Water Brochure.pdf

Crawford, E., \& Beveridge, R. (2013). Strengthening BC's agriculture sector in the face of climate change. Victoria, B.C., Canada: Pacific Institute for Climate Solutions. Retrieved from http://pics.uvic.ca/sites/ default/files/uploads/publications/Strengthening BC $\% 27 \mathrm{~s}$ Agriculture Sector 0.pdf

Dai, A. (2013). Increasing drought under global warming in observations and models. Nature Climate Change, 3, 52-58. http://dx.doi.org/10.1038/nclimate1811

Garland, M. R. (1990). UBC guide to gardening in British Columbia. Vancouver, B.C., Canada: University of British Columbia.

Green, R. (2006). Case studies of Agricultural Land Commission decisions: The need for inquiry and reform. Victoria, B.C., Canada: University of Victoria. Retrieved from http://www.elc.uvic.ca/docu ments $/$ ALR $\% 20$ Final $\% 20$ Report $\% 20 \% 28$ FINAL2\%29.pdf

Intergovernmental Panel on Climate Change. (2014). Summary for policymakers. In T. F. Stocker, D. Qin, G.-K. Plattner, M. Tignor, S. K. Allen, J. Boschung, A. Nauels, Y. Xia, V. Bex, \& P. M.
Midgley (Eds.), Climate change 2013: The physical science basis. Contribution of Working Group I to the Fifth Assessment Report of the Intergovernmental Panel on Climate Change. (pp. 1-30) Cambridge, United Kingdom: Cambridge University Press. http://dx.doi.org/10.1017/CBO9781107415324. $\underline{004}$

Johansen, C., Haque, M. E., Bell, R. W., Thierfelder, C., \& Esdaile, R. J. (2012). Conservation agriculture for small holder rainfed farming: Opportunities and constraints of new mechanized seeding systems. Field Crops Research, 132, 18-32. http://dx.doi.org/10.1016/i.fcr.2011.11.026

Jungen, J. R. (1980). Soil resources of the Nelson map area [RAB Bulletin 20]. Kelowna, B.C., Canada: B.C. Ministry of Environment. Retrieved from http://www.env.gov.bc.ca/esd/distdata/ ecosystems/Soils_Reports/bc28_report.pdf

Miller, M., Anderson, M., Francis, C. A., Kruger, C., Barford, C., Park, J., \& McCown, B. H. (2013). Critical research needs for successful food systems adaptation to climate change. Journal of Agriculture, Food Systems, and Community Development, 3(4), 161175. http://dx.doi.org/10.5304/jafscd.2013.034.016

Minot, N., \& Pelijor, N. (2010). Food security and food self sufficiency in Bhutan. Washington, D.C.: International Food Policy Research Institute. https://www.ifpri.org/publication/food-securityand-food-self-sufficiency-bhutan

North Kootenay Lake Community Services Society. (2013). Crown Land Project and Farmers to Farms The West Kootenay Farmer Land Bank database. Retrieved June 2014 from https://web.archive.org/ web/20140722034809/http://nklcss.org/food.php

Ostry, A. (2010). Food for thought: The issues and challenges of food security. Vancouver, B.C., Canada: Provincial Health Services Authority. Retrieved from http://www.phsa.ca/Documents/foodforthought issueschallengesoffoodsecurity.pdf

Ostry, A., Miewald, C., \& Beveridge, R. (2011). Climate change and food security in British Columbia. Victoria, B.C., Canada: Pacific Institute for Climate Solutions. Retrieved from http://pics.uvic.ca/ sites/default/files/uploads/publications/Food $\% 20$ Security 2011.pdf

Otto, S. (1993). The backyard orchardist: $A$ complete guide to growing fruit trees in the bome garden. Maple City, Michigan: OttoGraphics. 
Runka, G. G. (1973). Methodology: Land capability for agriculture: B.C. land inventory (CLI). Kelowna, B.C., Canada: B.C. Department of Agriculture. Retrieved from https://www.alc.gov.bc.ca/assets/alc/ assets/library/agricultural-capability/methodology land capability for agriculture bcli 1973.pdf

Statistics Canada. (2011). 2011 census of agriculture: Farm and farm operator data. Retrieved from http://www.statcan.gc.ca/ca-ra2011/indexeng.htm

Steinman, J. (2011). Towards a regional food system alliance development strategy for the West Kootenay. Nelson, B.C.,
Canada: Columbia Basin Trust. Retrieved from http://www.cbrdi.ca/rdi-resources/towards-aregional-food-system-alliance-developmentstrategy-for-the-west-kootenay/

Turnbull, E. G. (1988). Ghost towns and drowned towns of West Kootenay. Victoria, B.C., Canada: Heritage House Publishing Company.

University of Wisconsin-Extension \& University of Minnesota. (1992). Alternative field crops manual. University of Wisconsin Cooperative Extension Service. Retrieved from

http://www.hort.purdue.edu/newcrop/afcm/ 